dostępnej polskiemu czytelnikowi we wcześniejszych publikacjach innych autorów, analizuje uwarunkowania, które mają podstawowy wpływ na kształt i funkcjonowanie EBPiO, nie ograniczają się one tylko do najważniejszych państw Unii Europejskiej, ale prezentują także interesy mniej znaczących członków UE. Do tego w trzeciej części dochodzi szczegółowa prezentacja Europejskiej Strategii Bezpieczeństwa oraz budowy zdolności operacyjnych UE w zakresie zarządzania kryzysami. Całość dopełnia bardzo dokładny opis prowadzonych misji cywilnych i wojskowych. Warto zwrócić uwagę także na wykorzystywane pozycje bibliograficzne, które stanowią w większości wypadków publikacje zagraniczne, co spowodowane jest m.in. niskim zainteresowaniem tym tematem w naszym kraju oraz wykorzystywanie szerokiego spektrum dokumentów dotyczących $\mathrm{EPBiO}$, a także polityk bezpieczeństwa i obrony prowadzonych przez poszczególne państwa członkowskie. Dlatego też bibliografia może stanowić ważną wskazówkę dla poszukujących bardziej szczegółowych informacji dotyczących tematyki zawartej w książce. Zasadniczo jedynym mankamentem, który można zarzucić tej książce, z którego zresztą Autorka na wstępie się tłumaczy, jest nieuwzględnienie roli państw, które stały się członkami UE po 2004 r., w kształtowaniu Europejskiej Polityki Bezpieczeństwa i Obrony. Przez ten fakt traci się z pola widzenia możliwą ewolucję EPBiO pod wpływem interesów dwunastu nowych państw członkowskich.

Książkę autorstwa Irmy Słomczyńskiej, można polecić wszystkim zainteresowanym rozwojem i funkcjonowaniem polityki zagranicznej i bezpieczeństwa Unii Europejskiej, a w szczególności tym, dla których aspekt militarny współpracy państw członkowskich UE jest najbardziej interesujący.

ADAM JASKULSKI

\title{
Zbigniew Czachór (red.), 50 lat i co dalej? Europa i Unia Euro- pejska między integracjq a atomizacjq..., WN INPiD UAM, Poznań 2007, ss. 337.
}

Instytut Nauk Politycznych i Dziennikarstwa poznańskiego UAM od wielu lat zajmuje się analizą teorii integracji europejskiej, czego zwieńczeniem jest powstanie w 2004 roku Pracowni Badań nad Integracją Europejską. Publikacja 50 lat i co dalej? Europa i Unia Europejska między integracja a atomizacja... jest efektem dwóch wydarzeń naukowych, których organizatorem obok wspomnianej Pracowni był również Ośrodek Badań i Edukacji Europejskiej. Kompilacja materiałów pochodzących z konwersatorium badawczego pt. „Integracja versus atomizacja. W poszukiwaniu nowych teorii oraz konstrukcji analitycznych wyjaśniających dynamikę zmian w systemie Europy i Unii Europejskiej”, które miało miejsce w listopadzie 2006 r. oraz referatów z konferencji naukowej poświęconej 50 rocznicy podpisania Traktatów Rzymskich, dała asumpt do powstania powyższej pracy pod redakcją naukową prof. Zbigniewa Czachóra.

Na treść publikacji składają się dwadzieścia dwa artykuły naukowe traktujące często w dość szeroki sposób kwestię integracji europejskiej, jak i samą Unię Europejską (UE). Teksty zawarte w książce podzielono na cztery zasadnicze grupy. Intencją owej recenzji nie jest streszczanie całości, w związku z czym spośród wspomnianych grup omówione zostaną najciekawsze rozprawy.

W pierwszej z grup poruszającej kwestię $\mathrm{m}$.in. teorii integracji, został umieszczony tekst poznańskiego wykładowcy. Prof. Andrzej Gałganek w swym artykule zatytułowanym Neośredniowieczna analogia jako proces atomigracji wprowadził pojęcie, które jest połączeniem terminów atomizacji i integracji. Atomigracja jest procesem, którego źródeł na poziomie lokalnym, jak i ponadpaństwowym (systemowym) Autor dopatruje się w neośredniowiecznej koncepcji, zestawiając ją z teorią fragmentacji i konsolidacji Stuart J. Kaufmana. Uważa, iż analogia neośredniowieczna jest użyteczną przy opisie i rozumieniu współczesnych stosunków międzynarodowych, czyli postępującej atomizacji przez samookreślanie składowych systemu oraz wprowadzenia reżimu 
ekonomicznego o zasięgu międzynarodowym, czego przykładem jest funkejonowanie Unii. Ów artykuł jest rozbudowanym esejem naukowym omawiającym teorię integracji przez pryzmat kontinuum rozpadu i łączenia się systemu międzynarodowego.

Druga grupa artykułów obejmuje tematyką m.in. kwestie podstawowych pojęć integracji, tożsamości, języka, antagonizmów oraz religijności Europy. Spośród tekstów zakwalifikowanych do tejże grupy warto wskazać na Kryzys tożsamości europejskiej autorstwa prof. Stanisława Konopackiego, który wychodzi w swych rozważaniach od pojęcia „Innego” zaczerpniętego z lektury Ryszarda Kapuścińskiego. Owe stworzenie przez Europejczyków przeciwwagi konstytuowało do tej pory ich tożsamość. Jednakże Stary Kontynent wraz ze swą kulturą dotarł do pewnego ekstremum. Aby Unia Europejska mogła dalej egzystować i rozwijać się potrzebuje nowego oparcia, skonstruowania aktualnego modelu tożsamości od podstaw. Punktem wyjścia, zdaniem profesora, jest zredefiniowanie odmienności Europy, jako tej, która konstytuuje się w tym co określano jako inne. Nie mniej ważne jest branie odpowiedzialności za poszanowanie uniwersalnych praw i różnorodności, na co wskazuje przytaczany Jacques Derrida.

$\mathrm{Na}$ trzecią grupę, poruszającą kwestię uwarunkowań wewnętrznych i zewnętrznych integracji oraz problematykę integracji Polski z UE, składa się pięć referatów, z których wartym omówienia jest Dynamika procesu integracji europejskiej po rozszerzeniu w 2007 roku, autorstwa dr Beaty Przybylskiej-Maszner. Problem rozwoju Wspólnoty jest kwestią wyjątkowo aktualną i dynamiczną. Zdaniem Autorki, tempo rozszerzania struktur unijnych musi ulec zwolnieniu na rzecz wzmocnienia nadwerężonych procedur, które winny stać na straży budowania wspólnoty gospodarczej, handlowej, jak również wspólnej polityki zagranicznej i bezpieczeństwa. Artykuł, co równie ważne, ukazuje nam lapidarny rys historyczny najważniejszych wydarzeń w 50-letniej historii Wspólnot Europejskich.

Ostatnie sześć artykułów porusza tematy związane z polityką wspólnotową i zadaniami, które stoją przed Unią Europejską. Witold Ostant z Instytutu Zachodniego wskazuje w swym tekście $^{1}$ na zjawisko, jakim jest współpraca państw członkowskich UE w ramach Europejskiego Biura Policji w walce z terroryzmem międzynarodowym. Choć Biuro funkcjonuje od roku 1998 to jego kompetencje poszerzano kilkukrotnie. Autor artykułu wskazuje, iż wydarzenia z 11 września były przyczyną wskazania nowych zadań Europol'owi w postaci transgranicznej walki z terroryzmem. Pytaniem otwartym jest, czy i kiedy europejska agenda policyjna swą strukturą i działaniem zacznie przypominać FBI? Gdyż, co do potrzeby rozwoju Biura w tym kierunku, autor owej rozprawy zdaje się nie mieć wątpliwości.

Warto podkreślić, iż praca pod redakcją prof. Zbigniewa Czachóra mimo kilku błędów edytorskich zasługuje na uwagę, z racji szerokiego ujęcia kwestii zarysowanej w temacie niniejszej publikacji. Mnogość autorów gwarantuje w tym przypadku wielopłaszczyznowe spojrzenie na problem integracji i dezintegracji transnarodowej UE, która nie ma swego precedensu w skali, ani czasie. Drugą ważną kwestią, na którą warto zwrócić uwagę przy tejże pracy zbiorowej jest integracja środowiska akademickiego. Oprócz autorów związanych z poznańskim Uniwersytetem, pojawiły się również osoby z uczelni łódzkiej, warszawskiej oraz Ambasady RP w Dublinie. Należy ostatecznie podkreślić, iż 50 lat i co dalej?... winna być lekturą obowiązkową każdej osoby pragnącej spojrzeć na problematykę integracji europejskiej wielowymiarowo. Dychotomiczna optyka procesów integracji w kategoriach homogenizacji bądź atomizacji coraz częściej przestaje być wystarczającą, a niniejsza praca jest tego potwierdzeniem.

BŁAŻEJ GRYGO

1 Europejski Urząd Policji - Europol, jako instrument przeciwdziałania terroryzmowi w ramach kompetencji przedmiotowych Unii Europejskiej. 